\title{
PENDIDIKAN ISLAM DALAM PANDANGAN FAZLUR RAHMAN
}

\author{
M. Roihan Alhaddad \\ Sekolah Tinggi Ilmu Tarbiyah Raudhatul Ulum \\ Email: roihan.alhaddad@gmail.com
}

\begin{abstract}
Abstrak
Ditengah pergulatan pendidikan Islam dan dunia modern yang menurut Rahman terdapat dikotomi, maka ia mencoba menyatukanya demi menemukan esensi pendidikan Islam yang sesuai dengan tuntutan zaman. Harapanya adalah dengan dipadukanya pendidikan modern dan Islam maka kelak akan muncul tokoh-tokoh muslim yang tidak hanya memiliki pengetahuan agama yang luas tapi juga mampu berdialektika dengan realitas kehidupan sosial. Gagasan pemikiran pendidikan Fazlur Rahman berawal dari kegelisahanya akan anggapan bahwa pendidikan Islam ketinggalan jauh dibandingkan dengan Barat. Sampai pada batas tertentu, pandangan seperti ini dapat dibenarkan, ketika pendidikan itu dipandang dari sudut kemajuan di dunia ini saja

Pendidikan Islam bagi Rahman adalah suatu yang integral dan saling terkait, baik itu ilmu keduniaan (sains) dan ilmu agama atau keahiratan. Berdasarkan pada pandangan Fazlur Rahman tentang pendidikan, setidaknya terdapat dua model pendidikan yang berasal dari gagasanya. Yang pertama adalah pendidikan Islam yang kritis dan kreatif dan selanjutnya pendidikan Islam yang menjunjung moralitas yang tinggi.
\end{abstract}

Kata Kunci: Pendidikan Islam, Fazlur Rahman

\section{Pendahuluan}

Dunia pendidikan Islam terasa tidak henti-hentinya menjadi bahan pembicaran dalam berbagai diskursus para ilmuan. Sejak permulaan abad kesebelas yang dipelopori oleh filsuf muslim kenamaan seperti al-Ghazali (450/1058-505/1111), 1 sampai para pemikir abad modern sekarang ini, pendidikan Islam selalu memiliki ruang tersendiri sebagai topik bahasan. Bukan cuma sekedar telaah kritis atas berbagai kekurangan tetapi juga formulasi pemikiran menghadapi era pendidikan Islam di abad modern.

Salah satu cendekiawan muslim modren yang mencoba menemukan antara pendidikan Islam dengan realitas modren adalah Fazlur Rahman. Walaupun namanya lebih dikenal sebagai cendekiawan yang Qur'anik,2 tetapi tidak berarti

\footnotetext{
${ }^{1}$ Al-Ghazali dengan berbagai pemikiran pendidikanya, disebut sebagai rujukan bagi para Ilmuan bidang pendidikan sesudahnya. Bahkan ada yang mengatakan para penulis sesudah Al-Ghazali tidak lebih dari sekedar mengulang apa yang ia telah sebutkan sebelumnya. Lihat Hasan Asari, Nukilan Pemikiran Islam Klasik; Gagasan Pemikiran Al-Ghazali, (Yogyakarta : Tiara Wacana Yogya, 1999), hlm. 2

${ }^{2}$ Berbagai sarjana muslim memberikan penilaian yang relatif sama tentang Fazlur Rahman, Syafi' i Maarif menyebutnya sebagai pemikir yang Qur'an Oriented, sedangkan Nurcholis Madjid Menyebutnya orang yang Koranic, lihat Sutrisno, Fazlur Rahman “Kajian terhadap Metode, Epistimologi dan Sistem Pendidikan” , (Yogyakarta : Pustaka Pelajar, 2006), hlm. 5-8
} 


\section{Pendidikan Islam dalam Pandangan Fazlur Rahman M. Roihan Alhaddad}

meninggalkan sisi yang lain seperti pendidikan Islam. Hal ini terlihat dari sekian banyak buku yang ditulisnya terdapat juga buku yang mengulas tentang pendidikan.

Ditengah pergulatan pendidikan Islam dan dunia modern yang menurut Rahman terdapat dikotomi, maka ia mencoba menyatukanya demi menemukan esensi pendidikan Islam yang sesuai dengan tuntutan zaman. Harapanya adalah dengan dipadukanya pendidikan modern dan Islam maka kelak akan muncul tokoh-tokoh muslim yang tidak hanya memiliki pengetahuan agama yang luas tapi juga mampu berdialektika dengan realitas kehidupan sosial.

Mengingat begitu penting dan berperanya pemikiran pendidikan Fazlur Rahman dalam dunia pendidikan abab modern, maka penulis merasa perlu membahasnya dalam sebuah karya ilmiah ini. Bahasan dimulai dengan Sketsa Biografi Fazlur Rahman, Pemikiran Pendidikannya, dan Implikasi Pemikiranya Pendidikannya dalam dunia global.

\section{Sketsa Biografi Fazlur Rahman}

Fazlur Rahman lahir pada tanggal 21 september 1919 di daerah Hazara (anak benua India) yang sekarang terletak di sebelah barat laut Pakistan (Sutrisno, 2006:60) Dia lahir dalam sebuah keluarga muslim yang taat beragama. Seperti pengakuan Fazlur Raman sendiri keluarganya mempraktikan ibadah hari-hari secara teratur seperti sholat, puasa dan lain-lain. Ayahnya, Maulana Sahab Al-Din, adalah seorang alim terkenal lulusan Deoband.3 Rahman kecil beruntung memiliki seorang ayah yang betul-betul memperhatikan pendidikanya. Sehingga pada usia sepuluh tahun, Rahman telah hafal al-Qur'an seluruhnya.(Sutrisno, 2006:61) Kendatipun berpendidikan agama sistem tradisional, ayahnya sangat menghargai pendidikan sistem modern, hal ini banyak mempengaruhi pemikiran Fazlur Rahman dikemudian hari.(Hasbi Amirudin, 2000:9)

Pendidikan keluarga telah membentuk watak dan kepribadaan Fazlur Rahman dalam menghadapi kehidupan nyata. Menurut Fazlur Rahman, ada beberapa faktor yang telah membentuk karakter dan kedalamanya dalam beragama. Salah satu diantaranya adalah pengajaran tentang kejujuran, kasih sayang, serta kecintaan penuh dari ibunya. Hal lain adalah ayahnya tekun mengajarkan agama kepada Fazlur Rahman di rumah dengan disiplin tinggi sehingga dia mampu menghadapi bermacam peradaban dan tantangan di alam modern. (Hasbi Amirudin, 2000:10)

Hal penting yang juga mempengaruhi pemikiran kegamaan Fazlur Rahman adalah, lingkungan keluarga yang bermazhab Hanafi. Mazhab ini sebagaimana diketahui sebagai sebuah mazhab sunni yang lebih banyak menggunakan rasio (ra'yu) dibandingkan dengan mazhab sunni lainya. (Sutrisno, 2006:61) Selain itu ketika Fazlur Rahman hidup di Pakistan telah lebih dulu berkembang pemikiran

\footnotetext{
${ }^{3}$ Deoband adalah sebuah madrasah tradisional yang paling bergengsi di anak benua Indo Pakistan. Madrasah ini didirikan Muhammad Qasim Nanotawi pada 1867. Lihat M. Hasbi Amiruddin, Konsep Negara Islam Menurut Fazlur Rahman, (Yogyakarta : UII Press, 2000), hlm. 9
} 
P-ISSN : 2541-3686

yang agak liberal seperti yang dikembangkan oleh Syah Waliyullah (w. 1762), Sayyid Ahmad Khan (w. 1905), Sayyid Ameer Ali dan Muhammad Iqbal (w.1938). (Fazlur Rahman, 2001:8)

Pada tahun 1933, Rahman melanjutkan studinya ke Lahore dan memasuki sekolah modern. Pada tahun 1940, dia menyelesaikan BA-nya dalam bidang bahasa Arab pada Universitas Punjab. Kemudian, dua tahun berikutnya (1942), ia berhasil menyelesaikan Masternya dalam bidang yang sama pada Universitas yang sama pula. (Fazlur Rahman, 2001:62)

Setelah lulus dari Universitas Punjab Rahman menyadari bahwa keilmuan yang didapatnya masih cukup rendah, maka kemudian dia memutuskan untuk memperdalam ilmunya di Inggris. Keputusan ini dianggap suatu hal yang berani, sebab akan dianggap aneh kalau jika seorang muslim belajar di Eropa. Akan tetapi semangatnya yang kuat tidak mampu dihalangi oleh anggapan tersebut. Pada tahun 1946, ia masuk Oxford University, dan kemudian menyandang gelar Doktor di bidang sastra pada tahun 1950. (Sibawaihi, 2007:18)

Rupanya pengalaman studi di Inggris membuat Rahman betah menetap disana. Hal ini dibuktikanya dengan menjadi menjadi Dosen bahasa Persia dan filsafat Islam di Durham University Inggris pada 1950-1958. Selanjutnya, atas berbagai pertimbangan, ia peindah ke Mc Gill University Kanada untuk menjadi Associate Professor pada bidang Islamic Studies. Namun, tiga tahun kemudian, semangat patriotik kenegaraannya menjadikan Rahman kembali ke Negaranya. (Sibawaihi, 2007:19)

Pada masa pemerintahan Ayyub Khan yang berfikiran modern Rahman ditunjuk menjadi direktur pusat Lembaga Riset selama satu periode (1961-1968). Lembaga Riset yang dikelola Rahman berhasil menerbitkan dua jurnal Ilmiah, masing-masing Islamic Studies yang berbahasa Inggris beserta Fikru Nazr yang berbahasa Urdu. Dalam jurnaljurnal inilah, disamping media-media ilmiah lainya, Rahman mengemukakan gagasangagasan pembaharuanya yang selalu menimbulkan kontroversi akut berskala nasional di Pakistan. Islamic Studies, memang merupakan sebauh jurnal bertaraf internasional dan cukup bergengsi. Di dalam jurnal inilah beberapa sarjana asing menerbitkan riset-riset mereka, demikian pula staf peneliti di lembaga Riset tersebut. (Taufik, 1992:85)

Seiring dengan banyaknya kontroversi, Rahman merasa bahwa daerahnya belum bisa menerima pemikiran-pemikiran pembaharuan yang dilontarkanya. Akhirnya ia memutuskan untuk meletakan jabatanya itu dan hijrah ke Los Angeles menjadi Visiting Professor di Universitas California pada musim semi 1969. Pada musim gugur ia pergi ke Universitas Chicago sebagai profesor pemikiran Islam di universitas itu, Rahman menjadi guru besar yang dihormati. Ketenaran universitas ini disebabkan oleh penunjukan Rahman sebagai guru besarnya. Tidak kurang dari delapan tahun, Rahman menetap di Chicago, menulis, meneliti, dan mengkomunikasikan gagasanya hingga Tuhan memanggilnya pada 26 Juli 1988, karena serangan jantung. (Abdul Mustaqim, 2002:46) 


\section{Pendidikan Islam dalam Pandangan Fazlur Rahman M. Roihan Alhaddad}

\section{A. Pemikiran Pendidikan Fazlur Rahman}

Gagasan pemikiran pendidikan Fazlur Rahman berawal dari kegelisahanya akan anggapan bahwa pendidikan Islam ketinggalan jauh dibandingkan dengan Barat. Sampai pada batas tertentu, pandangan seperti ini dapat dibenarkan, ketika pendidikan itu dipandang dari sudut kemajuan di dunia ini saja. Sehingga dilema pun mencuat kepermukaan manakala umat Islam dihadapkan pada upaya untuk memaknai pendidikan tersebut dan mengejar ketertinggalanya. Menurut Rahman pembaharuan Islam dalam rangka mengejar ketertinggalan, harus dimulai dari pendidikan. Baginya pendidikan adalah satu-satunya pendekatan untuk penyelesaian jangka panjang atas problema-problema yang dialami masyarakat Islam saat ini. Mengenai hal tersebut dapat dilihat pernyataanya sebagai berikut:

"Pembaharuan Islam yang bagaimanapun yang mau dilakukan sekarang ini mestilah dimulai dengan pendidikan. Walaupun suatu orientasi yang Islamis mesti diciptakan pada tingkat pendidikan primer, tapi pada tingkat tinggilah Islam dan intelektualisme modern harus diintegrasikan untuk melahirkan suatu Weltanschaung Islam yang asli dan modern". (Fazlur Rahman, 2000:384)

Dari pernyataan di atas jelaslah bahwa menurut Rahman pendidikan mempunyai fungsi sentral sebagai pendekatan mengatasi permasalahan umat. Sayangnya, masih menurut Rahman sebagaimana dikutip oleh Abdul Munir Mulkan, strategi pendidikan Islam yang terlihat dewasa ini tidak benar-benar diarahkan pada tujuan yang positif, melainkan lebih cenderung bersifat defensif. Kecendrungan ini bertujuan untuk menyelamatkan pemikiran umat Islam dari pencemaran atau kerusakan yang ditimbulkan oleh dampak pemikiran barat yang muncul melalui berbagai disiplin ilmu, khususnya pemikiran yang akan menghancurkan standar moralitas Islam. Jika penolakan terhadap Barat itu terus dilakukan maka umat Islam akan terus-menerus berada dalam kemunduranya. Betapa tidak, harus diakui bahwa Barat saat ini telah tampil sebagai sebuah peradaban besar ilmu pengetahuan, terlepas dari bentrokan ideologi yang mungkin tercipta. Akan tetapi, menerima Barat bulat-bulat tanpa proses filterasi adalah hal yang juga tidak boleh dibiarkan. (Abdul Munir, 2010:78) Hal ini disinyalir oleh Rahman dalam tulisanya,

"Saya telah memberikan dua alasan bagi tidak adanya sekarang ini pendidikan yang kreatif dikalangan masyarakat Muslim; Pertama, semacam penelusuran yang pasif dan absurd atas sistem pendidikan masa penjajahan atau dalam kasus Turki, taqlid yang membudak kepada model Barat; Kedua, keterpesonaan para perencana pendidikan oleh ideologi kemajuan materil" (Fazlur Rahman, 2005:106)

Untuk itu, menurut Rahman dalam rangka mengatasi hal tersebut yang harus dilakukan adalah : Pertama, harus ada usaha untuk mengubah paradigma bahwa pendidikan Islam itu bersifat defensif dan hanya berorientasi pada akhirat. Orientasi pendidikan mestinya tidak berangkat dari satu titik tolak saja, melainkan dunia dan akhirat sekaligus. Orientasi pada keduanya tidak lantas harus dimaknai sebagai dua hal 
Volume 1 Nomor 1 Edisi Juni 2016

P-ISSN : 2541-3686

yang terpisah, tapi keduanya merupakan satu kesatuan integral. Dalam implementasinya orientasi pendidikan ini harus senantiasa bersumber pada al-Qur'an.

Kedua, umat Islam harus segera melakukan pengkajian ilmu-ilmu yang komprehensif. Diskriminasi terhadap ilmu-ilmu Barat mestinya tidak lagi dilakukan. Semua ilmu pengetahuan harus dilihat sebagai suatu rangkaian ilmu pengetahuan yang saling terkait. Umat Islam dalam hal ini mestinya mengembangkan usaha sistematis atas seluruh ilmu pengetahuan dengan tetap berdasarkan pada al-Qur'an. (Abdul Munir, 2010:79)

Dengan demikian pendidikan Islam bagi Rahman adalah suatu yang integral dan saling terkait, baik itu ilmu keduniaan (sains) dan ilmu agama atau keahiratan. Berdasar pada pandangan Fazlur Rahman tentang pendidikan di atas, setidaknya terdapat dua model pendidikan yang berasal dari gagasanya. Yang pertama adalah pendidikan Islam yang kritis dan kreatif dan selanjutnya pendidikan Islam yang menjunjung moralitas yang tinggi.

\section{Pendidikan Islam Kritis dan Kreatif}

Sifat kritis disini ditujukan oleh Rahman baik pada warisan Islam sendiri maupun pada peradaban Barat. Kritik terhadap peradaban Barat menjadi penting karena peradaban ini telah mendominasi peradaban dunia selama beberapa abad terakhir. Dengan dominasinya, peradaban Barat sangat besar pengaruhnya pada peradaban umat Islam sekarang. Oleh karena itu, para pemikir Muslim harus betul-betul kritis terhadap peradaban tersebut.

Fazlur Rahman dengan sikap kreatifnya berusaha untuk memberikan alternatif pemecahan terhadap permasalahan-permasalahan umat, termasuk masalah aktual, terutama masalah krisis pemikiran, masalah dikotomi Ilmu (ilmu agama dan ilmu umum), dan masalah dualisme dalam sistem pendidikan, yaitu sistem pendidikan tradisional (Islam) dan sistem pendidikan sekuler modern (umum). (Sutrisno, 2006:178179) Mengenai kegelisahan tersebut Rahman menuangkanya dalam sebuah tulisanya sebagai berikut :

“...Perbedaan yang sangat penting yang kemudian dibuat adalah antara sainssains agama ('ulum syar'iyyah) atau sains-sains tradisional (ulum naqliyah) dan sains-sains rasional atau sekular (ulum aqliyyah atau ghair syar'iyyah), yang sikap terhadapnya sedikit demi sedikit menjadi semakin kaku dan mencekik." (Fazlur Rahman, 2005:39)

Untuk mengatasi masalah masalah-masalah tersebut Rahman menawarkan solusi dengan grand teorinya yaitu double movement (gerakan ganda). ${ }^{4}$ Metode ini digunakan untuk mendobrak pendidikan yang selama ini tidak begitu relevan dengan kebutuhan umat. Dengan menerapkan metode ini diharapkan pendidikan Islam bisa menjawab

${ }^{4}$ Pada dasarnya metode ini digunakan Rahman sebagai metode dalam menafsirkan al-Qur' an. Metode pertama dengan mengkaji problem historis dimana pernyataan al-Qur' an tersebut merupakan jawabanya, sedangkan yang kedua yaitu memberi jawaban sesuai dengan latar belakang sosio historis dan ratio-logis. Lihat, Fazlur Rahman, Islam \& Modernity; Tranformation of an Intelektual Tradition, Terj. Ahsin Mohamad, hlm. 7 


\section{Pendidikan Islam dalam Pandangan Fazlur Rahman M. Roihan Alhaddad}

problem-problem umat. Metode ini diterapkan dengan cara, yaitu pertama ditujukan pada pemenuhan kompetensi peserta didik, dan gerak kedua diarahkan pada pragmatis dan fungsi peserta didik, misalnya peran sosial di masyarakat. Gerak pertama berupa penyadaran akan pentingnya peserta didik memiliki kompetensi tertentu yang memang dibutuhkan oleh umat, dan gerak kedua merupakan kompetensi peserta didik berperan dalam masyarakat setelah mereka selesai menempuh program pendidikan tertentu. (Sutrisno, 2006:69)

Selain itu, Rahman juga menekankan pentingnya pembaharuan pendidikan Islam, pembaharuan tersebut dapat dilakukan dengan cara, pertama membangkitkan ideology umat Islam tentang pentingnya belajar dan mengembangkan ilmu pengetahuan. Kedua, berusaha mengikis dualisme sistem pendidikan umat Islam. Pada satu sisi ada system pendidikan tradisional (agama). Kedua sistem pendidikan ini sama-sama tidak beresnya. Karena itu perlu ada upaya untuk mengintegrasikan keduanya. Ketiga, menyadari betapa pentingnya bahasa dalam pendidikan dan sebagai alat untuk mengeluarkan pendapatpendapat yang orisinil. Menurut Rahman, umat Islam lemah dalam bahasa. Keempat, pembaharuan dibidang metode pendidikan Islam, yaitu beralih dari metode mengulangulang (membeo) dan menghafal pelajaran ke metode memahami dan menganalisis. (Sutrisno dan Rahman, 2006:167)

Dari penjelasan di atas jelaslah bahwa Rahman dalam dunia menginginkan para intelektual muslim yang kritis terhadap budaya baik barat maupun Islam. Akan tetapi dibalik sifat ke kritisnya tersebut juga harus mampu memberikan solusi atau sebagai problem solving atas berbagai permasalahan umat.

\section{Pendidikan Yang Menjunjung Moralitas yang Tinggi}

Fakta bahwa Fazlur Rahman menempatkan manusia secara sosial sebagai objek kajianya terkait erat dengan pandanganya bahwa al-Qur'an merupakan dokumen untuk manusia, bukan risalah tentang Tuhan. Al-Qur'an tidak bercerita secara detail bagaimana Tuhan itu, melainkan bagaimana seharusnya manusia berperilaku di dunia ini. Strategi Al-qur'an semacam ini dalam pandangan Rahman mengandaikan bahwa al-Qur'an lebih berorientasi pada aksi moral ketimbang spekulasi intelektual. (Abdul Munir, 2010:79)

Dalam kaitan ini, pendidikan bukanlah proses mekanik belaka melainkan proses yang mempunyai ruh dimana segala kegiatanya diwarnai dan ditujukan pada keutamaan-keutamaan. Keutamaan-keutamaan ini terdiri dari nilai-nilai moral. Nilai moral yanhg paling tinggi adalah tauhid, sedangkan nilai moral yang paling rendah adalah syirik. Dengan prinsip keutamaan ini, pendidik bukan hanya bertugas menyediakan kondisi belajar bagi subyek didik atau pelajar, tetapi lebih dari itu turut serta membentuk kepribadianya dengan perlakuan dan keteladanan yang ditunjukan oleh pendidik tersebut

(Abdul Munir, 2010:79)

Jalan yang bisa menghantarkan moralitas tersebut dapat dilihat dalam bidangbidang kajian tingkat tinggi dengan nilai-nilai islam. Muatan moral al-Quran bisa memberikan orientasi atau arah baru terhadap hasil kajian keilmuan (science). Misalnya 
Volume 1 Nomor 1 Edisi Juni 2016

P-ISSN : 2541-3686

konsekuensi penyelidikan-penyelidikan yang dilakukan terhadap umat Islam, dan penerapan suatu keilmuan perlu dibingkai nilai-nilai moral dalam al-Qur'an seperti nilai Rahmatan lil alamin. (Maumunah, 2011:294)

Dari sini diketahui bahwa menurut Rahman intelektualisme yang tinggi tidaklah cukup untuk menghasilkan generasi yang baik. Akan tetapi perlu dibingkai dengan moralitas yang tinggi pula, dan baginya moralitas tersebut dapat dikembangkan dengan merujuk pada nilai al-Qur'an. Mungkin inilah sebabnya dalam pelbagai pembahasan Rahman tidak pernah lepas dengan kajianya pada al-Qur'an.

\section{B. Implikasi Pemikiran Pendidikanya dalam Dunia Global}

Sebelum membahas tentang implikasi pemikiran Fazlur Rahman dalam dunia global, kiranya perlu kembali melihat gagasan-gasan pemikiran Rahman. Gagasan pemikiran Fazlur Rahman adalah bersumber dari al-Qur'an. Rahman mengapresiasi temuan barat modern tetapi dengan mengakomodasi ide-ide ulama tradisional. Adegium ushul fiqih "al-Mukhafazhah 'ala al-qadim al-shalih wa al-akhz bi al-jadid al aslah" (tradisi lama yang baik tetap dipeliharan tapi temuan baru yang lebih baik harus di adopsi) dipastikan berlaku. (Sibawaihi, 2007:xvi)

Dalam kaitanya dengan pendidikan Islam di dunia global, setidaknya terdapat dua model pendidikan. Pertama, pendidikan Islam dalam pengertian praktis, yaitu pendidikan yang dilaksanakan di dunia Islam seperti yang diselenggarakan di Pakistan, Mesir, Sudan, Saudi, Iran, Turki, Maroko dan sebagainya, mulai dari pendidikan dasar sampai perguruan tinggi. Kedua, pendidikan tinggi Islam yang disebut oleh Rahman Intelektualisme Islam. Kedua model lembaga pendidikan yang berlabelkan Islam ini, pada dasarnya mengalami masalah yang sama, seperti ideologis, dualisme dalam sistem pendidikan, bahasa, dan problem pembelajaran. (Sutrisno dan Rahman, 2006:172)

Hal senada juga pernah diungkapkan oleh Prof. Mukti Ali atas pandanganya terhadap pendidikan Islam di Indonesia (pesantren). Menurutnya pendidikan Islam pada umumnya masih ketinggalan jauh dengan pendidikan umum "sekuler", dengan membandingkan IAIN pada saat itu dengan UI ataupun ITB. Dalam konteks pendidikan global pun demikian, pengawal peradaban dunia masih dikuasai oleh kampus-kampus sekuler seperti Harvard, Oxford University, Massacuset dan berbagai Universitas dunia di Australia, Singapore dan Eropa. ${ }^{5}$

Solusi atas pelbagai permasalahan yang menimpa dunia pendidikan yang ditawarkan Rahman secara teoritis memang sangat bagus dan menjanjikan sehingga mampu menghasilkan keilmuan yang komprehensif, holistik, dan kontekstual dimana kemudian dapat digunakan sebagai acuan pemecahan problem kekinian. Agaknya dalam pandangan penulis, solusi Rahman tersebut mulai diterapkan dalam dunia pendidikan saat ini. Hal ini dapat dilihat dengan mulai bersifat inkusifnya lembaga pendidikan Islam. Dalam konteks ke-Indonesiaan sifat terbuka pendidikan Islam itu semakin menemukan momentumnya dengan adanya transformasi IAIN menjadi UIN.

\footnotetext{
${ }^{5}$ Al Makin, Menggali Sosiologi Agama Versi Sapen; Refleksi Lokalitas Menjawab Pesan Globaliasasi, Makalah pada Seminar Jurusan Sosiologi Agama, UIN Sunan Kalijaga 1 Desember 2012
} 


\section{Pendidikan Islam dalam Pandangan Fazlur Rahman M. Roihan Alhaddad}

Secara berangsur-angsur dikotomi ilmu semakin terkikis yang diikuti semakin memudarnya pendidikan umat Islam Indonesia. Kecurigaan terhadap barat pun mulai hilang dengan banyaknya pelajar-pelajar yang melakukan studi ke Barat dengan tidak meninggalkan sifat kritisnya. Apabila hal demikian dikembangkan terus menerus, maka mimpi Rahman akan lahirnya ilmuwan muslim yang kritis dan kreatif serta mampu menyelesaikan problem kontemporer akan mudah terwujud.

\section{Simpulan}

Pemikiran pendidikan Fazlur Rahman pada dasarnya mencoba menemukan antara keilmuan Islam dengan Barat sebagai tonggak peradaban pada saat ini. Rahman menginginkan bangunan keilmuan yang integral, holistik dan kontekstual. Dengan menggunakan teori gerakan gandanya Rahman mengharapkan akan lahir ilmuwan yang kritis dan kreatif serta bermoralitas tinggi. Dengan demikian maka berbagai permasalan umat akan mudah teratasi.

Akan tetapi harus diakui bahwa dalam dataran praksis-nya, model pendidikan seperti ini menjadi bukanlah pekerjaan yang tidak mudah. Masih mengakarnya tradisi Taqdis al-Afqar al-Diniyyah (pensakralan pemikiran keagamaan) dan kecurigaan terhadap Barat pada sebagian besar umat muslim, dapat menghambat cita-cita pendidikan yang digagas Fazlur Rahman tersebut.

\section{DAFTAR PUSTAKA}

Amiruddin M. Hasbi, Konsep Negara Islam Menurut Fazlur Rahman, Yogyakarta : UII Press, 2000

Asari Hasan, Nukilan Pemikiran Islam Klasik; Gagasan Pemikiran Al-Ghazali, Yogyakarta : Tiara Wacana Yogya, 1999

Maumunah Binti, Perbandingan Pendidikan Islam, Yogyakarta: Teras, 2011

Mulkan Abdul Munir dkk, Antologi Kependidikan Islam, Yogyakarta : Jurusan Kependidikan Islam, 2010

Mustaqim Abdul \& Syamsudin Sahiron, Studi Al-Qur'an Kontemporer; Wacana Baru Berbagai Metodologi Tafsir, Yogyakarta : Tiara Wacana Yogya, 2002

Rahman Fazlur, Islam and Modernity, Transformation Of an Intelektual Tradition, terj. Ahsin Mohammad, Bandung : Pustaka, 2005

Islam, Terj. Ahsin Mohammad, Bandung : Pustaka, 2000

Revival and Reform in Islam, Terj. Aam Fahmia, Jakarta : Raja Grafindo Persada, 2001 
RAUDHAH Proud To Be Professionals Jurnal Tarbiyah)damiyah

Volume 1 Nomor 1 Edisi Juni 2016

P-ISSN : 2541-3686

Sibawaihi, Hermeneutika Al-Qur'an Fazlur Rahman, Yogyakarta : Jalasutra, 2007

Sutrisno, dan Rahman, Fazlur "Kajian terhadap Metode, Epistimologi dan Sistem Pendidikan", Yogyakarta : Pustaka Pelajar, 2006

Pendidikan Islam yang Menghidupkan; Studi Kritis terhadap Pemikiran Fazlur Rahman, Yogyakarta : Kota Kembang, 2006

Taufik Adnan Akmal, Islam dan Tantangan Modernitas; Studi atas Pemikiran Hukum Fazlur Rahman, Bandung : Mizan, 1992 
Pendidikan Islam dalam Pandangan Fazlur Rahman M. Roihan Alhaddad 